\title{
EDITORIALS
}

\section{A TIME OF TRANSITION}

It is evident from the masthead for this issue that this is a time of change for Horizons. It feels strange no longer to have the name of my friend and colleague, Rodger Van Allen, alongside mine, especially since we shared the task of launching Horizons. In the course of our many discussions, even over such initial details as choice of print and cover design, we developed a unity in our diversity. We came to appreciate that our varied interests and perspectives were complementary and hopefully served to enhance the Journal. So I must admit a special sense of loss at Rodger's resignation, while fully appreciating his desire to give time to other projects. I am pleased that Rodger has agreed to serve as associate editor which assures that his expertise will continue to be readily available.

Another person who is missed around this office is James E. Biechler who served as Horizons' Book Review Editor during the past five years. The tasks of the Review Editor are crucial to the operation and success of a journal. Jim's thoroughness and efficiency in selecting books, contacting reviewers, and editing copy were remarkable. But I also miss our "analysis" of the problems of the world of religion on the days we paperbagged our lunch around a desk at Horizons. However, Jim's talents will continue to be of service to all of us in his new position as Book Review Editor of The Journal of Ecumenical Studies.

A third person to whom Horizons bids farewell is William E. May whose contributions as Associate Editor are deeply appreciated. The need to devote time to other projects is again a factor in Bill's resignation. As one of the original team his efforts helped bring Horizons to its sixth year.

New faces include Walter E. Conn of Villanova University who has assumed the work of Book Review Editor. As the present issue shows, he does a masterful job.

Roderick Hindery of Temple University joins us as Associate Editor. We look forward to benefiting from his expertise in the area of ethics.

Horizons is fortunate to have the talents of a learned society as a resource and the financial support of Villanova University for a home office. That guarantees a continuity of quality and stability despite changing personnel. There has been an attempt to have the Associate Editors reflect the academic and regional spectrum of our membership, recognizing that certain functions, such as Book Review Editor, are best accomplished by a person who is accessible to the home base of Horizons which is so well staffed by our Editorial Assistant, Teresa Byrne. 
No one, including myself, is a permanent fixture on this Journal since it exists for the entire membership of the College Theology Society. So there will be more changes over the next two or three years. It is important that we welcome fresh and invigorating perspectives while we take care to ensure the continued quality and growth of Horizons.

-BERNARD P. PRUSAK

\section{ON CELEBRATING NEWMAN'S FAITH IN THE LAITY}

(A guest editorial from a member of the College Theology Society teaching at the University of Dayton.)

This year marks the centennial of John Henry Newman's elevation to Cardinal on May 12, 1879, which was the result of a request of England's Catholic laity as voiced by the Duke of Norfolk. Some reflections seem appropriate.

A number of sources give great credence to John Coulson's edition of Newman's On Consulting the Faithful in Matters of Doctrine (New York: Sheed \& Ward, 1961). Coulson's Introduction describes Newman's great concern for Catholic education. It is surprising that the Catholic Bishops of England did not share this fervor and resented these democratic tendencies. Bishop Ullathorne of Birmingham wrote to one proponent, Simpson, that the bishops found it "absolutely unnecessary that the reasons for our own actions should be explained and that the Catholic community should be informed of the grounds of our proceedings" (Coulson, p. 16).

In the heat of this debate Newman became the editor of Rambler, a Catholic journal which published articles somewhat critical of England's Rome-oriented conservative hierarchy. In his first edition, May 1859, Newman wrote in favor of people like Simpson. He addressed the bishops on the issue of community involvement.

we do unfeignedly believe ... that their Lordships really desire to know the opinion of the laity on subjects in which the laity are especially concerned. If even in the preparation of a dogmatic definition the faithful are consulted, as lately in the instance of the Immaculate Conception, it is at least as natural to anticipate such an act of kind feeling and sympathy in great practical questions (Coulson, p. 8).

Bishop Ullathorne became antagonized by Newman's editorial, and pressured him to give up his new position. The July 1859 issue of 